\title{
Cervix Epithelium
}

National Cancer Institute

\section{Source}

National Cancer Institute. Cervix Epithelium. NCI Thesaurus. Code C49218.

The varied epithelium of the cervix; which is composed of nonkeratinized stratified squamous cells distally, and simple columnar cells proximally. 